\title{
INSECT PESTS ASSOCIATED WITH WHITE AND CAUCASIAN CLOVER IN A BAY OF PLENTY DAIRY PASTURE
}

\author{
R.N. WATSON, F.J. NEVILLE and N.L. BELL \\ AgResearch, Ruakura Agricultural Research Centre, \\ Private Bag 3123, Hamilton
}

\begin{abstract}
Pasture plots containing white and Caucasian clover were established on a summer-dry coastal Bay of Plenty farm and maintained under dairy grazing into a second year. Of soil dwelling pests, grass grub and Tasmanian grass grub populations increased most rapidly, with fewer present under Caucasian clover. Foliar insect feeding, with up to $26 \%$ loss of leaf area in white clover, was caused by lepidopteran larvae of Zizina labradus and indigenous species of Epyaxa. Epyaxa rosearia was the most significant defoliating insect on Caucasian clover. This is the first time that Epyaxa has been implicated as a pest of pasture legumes.
\end{abstract}

Keywords: Trifolium repens, Trifolium ambiguum, insect pests, Zizina labradus, Epyaxa rosearia, Costelytra zealandica, Aphodius tasmaniae

\section{INTRODUCTION}

White clover (Trifolium repens)(WC) abundance varies seasonally in coastal Bay of Plenty dairy pasture, with very reduced levels sometimes extending over successive years (Watson et al. 1994). A combination of low soil moisture with high surface temperatures in summer can severely reduce WC growing point densities. Drought effects and subsequent recovery of WC are further exacerbated by clover cyst (Heterodera trifolii) and root knot (Meloidogyne spp.) nematodes. Surface stolonation of WC and a generally shallow root system make it vulnerable to environmental extremes. Caucasian clover (T. ambiguum $)(C C)$ is a perennial pasture legume which spreads from underground rhizomes and may provide for more reliable summer persistence. It is also resistant to several viruses which are debilitating to WC (Pederson and McLaughlin 1989). Caucasian clover has a reputation for persistence in temperate environments including New Zealand (Strachan et al. 1994; Moorehead et al. 1994), but has not been evaluated under dairying pasture or in the warmer, more northerly regions of New Zealand. There is little published information on the activity of pests and diseases in CC. Dymocket al. (1989) found roots of WC and CC supported similar larval growth rates in grass grub (Costelytra zealandica) while native weevils in Otago fed on both clovers, with seedlings of white clover potentially more susceptible (Barratt et al. 1993; Ferguson and Evans 1994).

White clover and CC were established after maize cropping on a coastal Bay of Plenty farm in September 1994. There were two objectives: a) to evaluate the buildup of pests and diseases in relation to the vigour cycle known for WC established after cereal cropping and b) to determine if the rhizomatous habit of $\mathrm{CC}$ provides it with advantages over WC under dairy grazing in a summer-dry environment. This paper reports on the presence of insect pests during the initial two years of the pasture evaluation.

\section{METHODS}

Eighth hectare plots $\mathrm{x} 4$ replicates each of cv 'Grasslands Kopu' white clover and 'Endura' Caucasian clover were sown as pure swards in September 1994 on a Paengaroa sandy soil from Kaharoa ash after 15 years of maize cropping. The 1 ha total area was fenced from within a larger area in maize which was not returned to pasture 
until the following year. In order to compare developments with the new pasture, two plots were established in old pasture in an adjacent paddock and monitored as necessary. The new pasture plots were grazed as a common pasture during the summer and autumn of the first year and were undersown with 'Yatsyn' ryegrass in July 1995, except for a $7 \mathrm{~m}$ strip across all plots maintained as a pure clover species sward. At the time of drilling, a $7 \mathrm{~m}$ strip of the ryegrass was also drilled with $2 \mathrm{~kg} / \mathrm{ha}$ chlorpyrifos (Suscon Green 20\% slow release granule) to protect plants from an expected outbreak of grass grub. Small mowing plots $(5 \times 5 \mathrm{~m})$ with fungicide and nematicide treatments were established on both pure clover and ryegrass undersown areas for determination of pasture yield responses (not presented here). These plots were mown immediately before the remaining area was grazed as part of a dairy rotation.

Grass grub and other soil insects were sampled with a $10 \mathrm{~cm}$ diam. soil corer and hand sorted from each grazed plot in autumn 1995 (30 samples/ plot) and 1996 (20 samples/plot). In the second season samples were also taken from the chlorpyrifos treated areas. Inter-veinal feeding by caterpillars of the common blue butterfly (Zizina labradus) was evident on both clover species during summer 1994/5. When irregular leaf scalloping was also observed on CC in autumn 1995 examination of the sward beneath damaged leaves revealed the presence of small looper caterpillars. These were reared in the laboratory on caged transplanted CC to confirm that these caterpillars had caused the leaf damage observed and that they could be reared on CC. Emerged adults were sent to C. Green, Auckland for identification. On 22.2.96 and 26.3.96 growth and species composition of small subplots within grazed WC pasture observed to have high or low vigour clover was assessed. One hundred, and subsequently 50, WC leaves from herbage dissection samples on these respective sampling dates from each plotlet were assessed for leaf damage corresponding to each species of caterpillar. Leaf area consumed from each leaflet was estimated to the nearest $10 \%$. In February adults of the common blue were sampled from the grazed WC and CC plots by taking $4 \times 90^{\circ}$ sweeps per plot with a sweep net. Very few adults of the second lepidoptera, (Epyaxa spp.), were captured in the sweep net so numbers were sampled over a twenty minute interval from within $\mathrm{CC}$ and WC plots by parting the vegetation to disturb moths, which typically flew up and alighted some distance away. The moths had to be seized before they could disappear beneath the canopy again. Data were analysed for differences without transformation.

\section{RESULTS AND DISCUSSION}

White clover established complete ground cover within 3-4 months from sowing which suppressed weeds effectively. Very vigorous growth resumed into the second spring although patches of weaker growth appeared from late spring and became progressive during summer 1995/6. By contrast, CC developed poor ground cover in the first year and summer grass (Digitaria sanguinalis) became a dominant weed. A satisfactory density of CC plants remained beneath this cover and from spring 1995 the stand thickened considerably as new crowns established from rhizome growth. A small-leafed local ecotype of WC also became established as a weed contaminant but was dominated by CC during the second summer, contributing $9.5 \%$ to herbage yield by January 1996. These agronomic differences may have influenced subsequent insect populations in addition to those of clover species directly.

\section{Soil insect pests}

In autumn 1995 grass grub had increased to $74 \pm 15 \mathrm{SE}$ and $55 \pm 6 / \mathrm{m}^{2}$ in WC and CC respectively and a low population of Tasmanian grass grub $\left(6 / \mathrm{m}^{2}\right)$ was recorded under CC only (Table 1). In April 1996 there were $46 \%$ more grass grub under untreated WC $\left(286 \pm 27 / \mathrm{m}^{2}\right)$ than untreated CC $\left(196 \pm 29 / \mathrm{m}^{2}\right)(\mathrm{P}<0.05$; Table 1). Numbers of grass grub were similar in clover species in chlorpyrifos treated plots, but with an overall reduction of $53 \%$ compared with untreated pasture. Statistical analysis of chlorpyrifos as a main effect was invalidated by the lack of randomisation of treatments. It is possible that grass grub fed closer to the surface in the shallower rooted white clover thereby forcing closer contact with chorpyrifos granules and achieving a slightly higher mortality. 
Tasmanian grass grub are largely foliar feeding and prefer grass to clover, and open vegetation for oviposition. They may have been attracted to summer grass on CC plots in year 1. In 1996 there were $96 \%$ more Tasmanian grass grub on treated and untreated white clover $\left(79 / \mathrm{m}^{2}\right)$ compared with CC $\left(40 / \mathrm{m}^{2}\right)$ (SED 1.4; $\left.\mathrm{P}<0.001\right)$. There was a significant clover species $\mathrm{x}$ chlorpyrifos interaction $(\mathrm{P}<0.05)$, with numbers increased and decreased slightly on treated WC and CC respectively.

TABLE 1: Mean numbers of grass grub and Tasmanian grass grub/m $\mathbf{m}^{2}( \pm$ S.E. $)$ in new pasture containing two clover species and in adjacent old pasture in May/June 1995 and April 1996, with and without chlorpyrifos in year 2.

\begin{tabular}{lcccccc}
\hline & \multicolumn{2}{c}{ Caucasian clover } & \multicolumn{2}{c}{ White clover } & \multicolumn{2}{c}{ Old pasture } \\
& 1995 & 1996 & 1995 & 1996 & 1995 & 1996 \\
\hline $\begin{array}{l}\text { grass grub } \\
\text { - chlorpyrifos }\end{array}$ & $54.7(5.6)$ & $196(29)$ & $76.4(14.6)$ & $286(27)$ & $66.8(41.4)$ & $25.5(12.7)$ \\
+chlorpyrifos & - & $115(15)$ & - & $108(20)$ & - & - \\
& & & & & & \\
Tasmanian grass grub & & & & & \\
- chlorpyrifos & $6.4(3.7)$ & $47.7(12.3)$ & 0.0 & $68.4(8.3)$ & $15.9(9.5)$ & $12.7(6.4)$ \\
+chlorpyrifos & - & $31.8(15.0)$ & - & $87.5(10.5)$ & - & - \\
\hline
\end{tabular}

The density of other soil pest populations was negligible with the most numerous by autumn 1996 being black beetle (Heteronychus arator) at $2.8 / \mathrm{m}^{2}$ and whitefringed weevil (Naupactus (=Graphognathus) leucoloma) at $2.0 / \mathrm{m}^{2}$. In the adjacent site containing old pasture grass grub and Tasmanian grass grub were present (Table1) as well as black beetle and whitefringed weevil recorded at $15.9 \pm 3.2$ and $41.3 \pm 15.9 / \mathrm{m}^{2}$ respectively. Soldier fly (Inopus rubriceps) larvae were detected in $43 \%$ of soil samples from the old pasture but were not found in soil from new pasture. Thus it would appear that grass grub and Tasmanian grass grub had undergone relatively rapid increases in populations in the new pasture compared with the other pest species. This may reflect the relative mobility of the adult stages of the grass grub species and the fact that the pasture was relatively isolated from adjacent pasture initially.

\section{Foliar insects}

Caterpillars taken from beneath damaged CC in May 1995 and reared in the laboratory on this plant caused irregular scalloping damage to leaves typical of that observed in the field. The caterpillars pupated in May/June and emerged during June/ July. Three of these moths were identified as male Epyaxa rosearia Doubleday and one as a male of E. lucidata Walker. Epyaxa is an Australasian genus of Geometrid moth with three species including E. rosearia and E. lucidata native to New Zealand (Dugdale 1988). There is very little published information on the distribution and bionomics of these species. Epyaxa have not previously been recorded as damaging clovers but we have observed feeding on pasture herbs, particularly Plantago spp. The moths are more active in the evening, are attracted to light and have been observed to fly in Auckland 'at most times of the year' (C.J. Green pers. comm.). The moths were widely evident in Waikato/ Bay of Plenty in 1996. Feeding damage on clover is distinct from common blue larval feeding and consists of irregular scalloping of the leaf margins and occasionally, the centre portion of leaves. Feeding may occur on the margin of unfolded leaves producing symmetrical damage on both margins of each trifoliate leaflet when the leaf is opened. Occasionally the whole leaf lamina is consumed or the leaf is destroyed by feeding on the stem. In the present field trial leaf damage was common in more rank WC, and was the most common form of invertebrate defoliation of $\mathrm{CC}$ during the summer and autumn.

Pasture sweeps taken in February 1996 showed more butterflies of the common blue were associated with white clover $(32.8 \pm 4.1)$ than with Caucasian clover 
(7.0 \pm 1.8$)$. There were no significant numbers of other potential pests, e.g. other Lepidoptera or Hemiptera, in sweep samples. Thirteen of the moths were collected from CC and 16 from WC, all females of E. rosearia. The moths preferred more rank vegetation within pasture.

In February and March 1996, Epyaxa removed more leaf area and attacked a greater proportion of leaves than larvae of the common blue $(\mathrm{P}<0.01$; Table 2$)$. Damage was reduced in March compared with February, particularly for the common blue. The common blue removed a higher proportion of leaf area and attacked a higher proportion of leaves on low vigour compared with high vigour $\mathrm{WC}(\mathrm{P}<0.05$; Table 2$)$. Epyaxa also consumed a greater proportion of leaf on low vigour WC, but the incidence of leaf attack was more similar, reflecting the larger leaf size of the high vigour clover. As there was a very low incidence of individual leaves damaged by both caterpillars, the incidence of leaf damage is roughly additive. Thus, up to $90 \%$ of the leaves bore some form of insect feeding at this time of the year and this affected up to $26 \%$ of the total leaf area available.

TABLE 2: Mean $\%$ white clover leaf area removed, and \% of trifoliates and whole leaf numbers affected by caterpillars of two Lepidoptera species in pasture on 22 February and 26 March $1996( \pm \mathrm{SE})$.

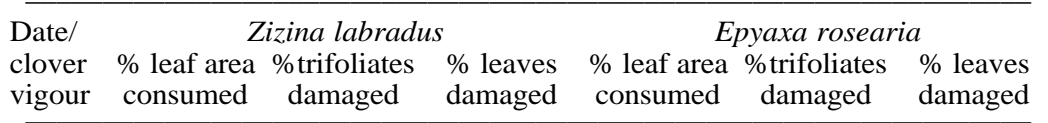

\begin{tabular}{lcrrrrr}
\hline 22.2.96 & & & & & & \\
high & $0.87(0.23)$ & $4.7(1.5)$ & $9.5(3.6)$ & $10.1(1.7)$ & $32.2(3.8)$ & $52.0(4.3)$ \\
low & $10.1(2.5)$ & $37.9(6.9)$ & $51.5(6.8)$ & $16.1(2.0)$ & $32.8(2.8)$ & $41.8(4.4)$ \\
26.3.96 & & & & & & \\
high & $1.1(0.4)$ & $5.7(1.6)$ & $11.5(2.5)$ & $5.3(1.3)$ & $22.3(3.9)$ & $35.5(5.4)$ \\
low & $4.6(1.8)$ & $15.9(3.7)$ & $22.5(3.7)$ & $10.3(1.5)$ & $27.1(3.8)$ & $37.5(5.9)$ \\
\hline
\end{tabular}

The common blue butterfly is frequently observed in northern pasture during summer but it is not generally known that the caterpillars feed on pasture legumes. Damage symptoms of inter-veinal and leaf surface feeding can be confused with feeding by slugs (e.g. Deroceras spp.) or clover flea (Sminthurus viridis). It is possible to find WC severely defoliated by blue butterfly during summer particularly in arid areas or sunny situations such as north faces of gullies, although damage to legume production has only been recorded in Maku lotus (Lotus pedunculatus) (East et al. 1978). BothZ. labradus and E. rosearia adults were very abundant in the wider coastal Bay of Plenty district during January - March 1996, an unusually moist summer with generally more rank growth and abundant clover present. While leaf feeding symptoms reaching the proportions reported in this paper were also widely apparent, because of the general abundance of growth, damage may not have been limiting to clover persistence (East et al.1978) or to dairy production.

\section{CONCLUSIONS}

Grass grub and Tasmanian grass grub were the main soil dwelling insect pests to establish in pasture containing WC or CC by the second year. Both insects had lower populations in $\mathrm{CC}$ than in WC. It is possible that neither pest had reached maximum population densities in the pasture by year two. Larvae of the common blue butterfly and the native moth,Epyaxa rosearia, were the main leaf defoliating species, consuming up to $26 \%$ of WC leaf area available during summer. The common blue was more prevalent on WC than CC and was more damaging on slower growing, less rank patches of WC. E. rosearia was the greatest defoliating pest in CC. It is possible that E. rosearia may not reach the levels recently observed in coastal Bay of Plenty during drier seasons with less clover abundance and greater summer utilisation of pasture. 


\section{ACKNOWLEDGEMENTS}

We express our sincere thanks to Margaret and Rex Benner for their generous hosting of the trial; to BOP Fertiliser Ltd for sponsoring fertiliser management and to local contractors who have provided their services. We gratefully acknowledge the support and interest of Bay Milk Products Ltd and farmers in the Coastal Producer Group; Chris Green, Department of Conservation, Auckland Conservancy, for identifying Epyaxa and providing useful background information; and Catherine Cameron for biometrical analyses.

\section{REFERENCES}

Barratt, B.I.P., Jones, P.A. and Ferguson, C.M., 1993. Screening legumes for susceptability to broad-nosed weevils (Coleoptera: Curculionidae). Proc. 6th Aust. Grassl. Invert. Ecol. Conf:: 189-194.

Dugdale, J.S., 1988. Lepidoptera - annotated catalogue, and keys to family-group taxa. Fauna of N.Z. No. 14. DSIR, Wellington. 262 Pp.

Dymock, J.J., van den Bosch, J., Caradus J.R. and Lane, G.A., 1989. Growth and survival of grass grub, Costelytra zealandica (White) (Coleoptera: Scarabeidae) on Trifolium species and T. repens x T. uniflorum hybrids. N.Z. J. Agric. Res. 32: 389-394.

East, R., Watson, R.N. and Welsh, R.D., 1978. Damage to pasture legumes by larvae of the common blue, Zizina otis labradus (Lepidoptera: Lycaenidae). The N.Z. Entomologist 6: 390-391.

Ferguson, C.M. and Evans, A.A., 1994. Field screening of seedling dryland legume species for susceptability to insect feeding. Proc. 1994 N.Z. Conf. on Sust. Land Manag., Lincoln, Canterbury: 227-231.

Moorhead, A.J.E., White, J.G.H., Jarvis, P., Lucas, R.J. and Sedcole, J.R., 1994. Effect of sowing method and fertiliser application on establishment and first season growth of Caucasian clover. Proc. N.Z. Grassld. Assoc. 56: 91-95.

Pederson, G.A. and McLaughlin, M.R., 1989. Resistance to viruses in Trifolium interspecific hybrids related to white clover. Plant Dis. 73: 997-999.

Strachan, D.E., Nordmeyer, A.H. and White, J.G.H., 1994. Nutrient storage in roots and rhizomes of hexapliod Caucasian clover. Proc. N.Z. Grassld. Assoc. 56: $97-$ 99.

Watson R.N., Bell, N.L., Neville, F.J. and Harris, S.L., 1994. Improving pasture sustainability by reducing the impact of clover nematodes. Pp. 83-85 In: Soil Biota: Management in Sustainable Farming Systems. C.E Pankhurst. (Poster papers). CSIRO, Australia. 